\title{
Impact of the E4L Project on Food Security and Livelihoods Among Beneficiaries in Savelugu Municipality of Northern Region, Ghana
}

\author{
Alhassan Bawa ${ }^{1, *}$, Lukman Yussif ${ }^{2}$ \\ ${ }^{1}$ Department of Agro Enterprise Development, Faculty of Applied Sciences and Technology, Ho Technical University, Ho, Ghana \\ ${ }^{2}$ Community Life Improvement Programme, Tamale, Ghana
}

Email address:

abawai1@yahoo.com (A. Bawa), abnaive@gmail.com (A. Bawa)

${ }^{*}$ Corresponding author

\section{To cite this article:}

Alhassan Bawa, Lukman Yussif. Impact of the E4L Project on Food Security and Livelihoods Among Beneficiaries in Savelugu Municipality of Northern Region, Ghana. International Journal of Science, Technology and Society. Vol. 9, No. 2, 2021, pp. 37-42.

doi: $10.11648 /$ j.ijsts.20211002.11

Received: December 22, 2020; Accepted: December 31, 2020; Published: March 12, 2021

\begin{abstract}
Agricultural production is the main activity in the northern sector of Ghana and is practiced mainly on seasonal and subsistence level. Most farmers in Northern Ghana are therefore food insecure owing to post-harvest, the seasonal of nature of agriculture, coupled with inadequate modern agricultural technologies. Adoption of modern agricultural technologies and cultural practices such as irrigation, fertilizer application, use of resistant varieties, good planting and harvesting times, among others might be the panacea to increased agricultural production and improved food security and livelihoods among farmers in northern Ghana. The study therefore sought to assess the impact of the Empowerment for Life (E4L) programme intervention on food security and livelihood among beneficiary women and farmer groups in Savelugu/Nanton Municipal of Northern region of Ghana. Out of several project interventions that are implemented in the Northern region, the purposive sampling technique was used to select the Empowerment for Life (E4L) programme for the study. Out of the five operational districts of the Empowerment for Life (E4L) programme, the Savelugu/Nanton municipal was selected through simple random sampling. The simple random sampling technique was again used to select ten beneficiary groups, out of a total of seventeen beneficiary groups in the Savelugu/Nanton municipal, for the study. The purposive sampling technique was used to select 45 beneficiary farmers, 40 beneficiary women and 5 members of E4L staff. In all, 100 respondents were selected for the study. The study revealed that majority of the beneficiary farmers have had improved food security through the adoption of improved agronomic practices and improved linkage between farmers and other actors in agricultural value chain. The study further established that the livelihoods of beneficiary farmers have been improved through improved capacity building, information sharing and improved access to productive resources such as land, labour and farm inputs. The study also revealed that in times of difficulties, majority of the farmers relied on their savings and/or sale of property as the mitigation measure or coping strategy. It is recommended that capacity building of farmers on agronomic practices and improved modern methods of farming should be intensified to further sharping the skills of farmers for increased productivity and hence, improved food security and livelihoods.
\end{abstract}

Keywords: Livelihoods, Food Security, E41 Programme, Beneficiary Farmer Groups, Ghana

\section{Introduction}

About 97.9 percent of households in Northern Ghana are engaged in crop farming such as maize, rice, sorghum, soy beans, cowpea, cassava, yam, cotton and vegetables, with few households engaging in poultry, livestock and pig rearing. Agricultural production is therefore the main activity in the northern sector of Ghana and is practiced mainly on seasonal and subsistence level.

Agriculture is heavily dependent on rainfall, which is highly 
unpredictable and erratic in nature. In recent times, adoption of modern agricultural technologies and cultural practices such as irrigation, fertilizer application, use of resistant varieties, good planting and harvesting times, among others might be the panacea to increased agricultural production and improved food security and livelihoods among farmers in northern Ghana. However, the adoption of these modern practices is hindered by financial constraints as these farmers are smallholder farmers with limited financial support. Commercial banks, private partners and insurance companies are often not ready to support them adopt and apply these technologies.

Challenges in the agricultural sector are not only limited to cultivation, there are serious concerns when it comes to postharvest storage and marketing, human resource and managerial skills, natural resource management, technology development and food insecurity. The major cause of food insecurity in northern Ghana is therefore, attributable to the use of bad farming practices and postharvest losses. Food security is a complex phenomenon resulting from multiple causes which are food availability, food accessibility, food utilization and food stability. About 5\% of Ghana's population are food insecure and about 2 million people are vulnerable to become food insecure.

The study therefore sought to evaluate the impact of the Empowerment for Life (E4L) programme intervention on food security and livelihood among beneficiary women and farmer groups in Savelugu/Nanton Municipal of Northern region of Ghana.

In view of the huge capital and other resources that the E4L programme is investing to improve on the food security and livelihood of the rural women and farmer groups, it will be appropriate to find out if the efforts of the project are yielding any significant results.

\section{Methodology}

\subsection{The Study Area}

The Savelugu/Nanton Municipal is an administrative area in Northern region of Ghana. It lies on Latitude $9^{\circ} 37^{1}$ $27.88^{11} \mathrm{~N}$ and Longitude $0^{\circ} 49^{1} 31.08^{11} \mathrm{E}$ with a population of 139,283 , representing 5.1 percent of the Region's total population [1]. Males constitute 48.5 percent and females represents 51.5 percent. The Savelugu/Nanton Municipal shares boundaries to the north with West Mamprusi district, Kumbungu district to the west, Sagnarigu Municipality to the south and Karaga district to the east.

Sixty percent of the population is rural. As high as 89.3 percent of households in the district are engaged in agriculture. In the rural localities, eight out of ten households $(93.3 \%)$ are agricultural households while in the urban localities, 83.3 percent of households are into agriculture. Most households in the district (97.0\%) are involved in crop farming. Poultry (chicken) is the dominant animal reared in the district. The indigenous people are Dagombas; however, there are other tribes like Fulani and Frafras who engage in farming and livestock rearing.

\subsection{Research Design}

The research design is the overall plan for collecting data in order to answer the research questions. It also includes the specific data analysis technique or methods that the researcher intends to use. The research methodology used for the study was field survey. The instruments that were used for data collection were questionnaires and interview schedules. The phenomenon under investigation is the effect of the Empowerment for Life (E4L) programme intervention on food security and livelihood among beneficiary women and farmer groups in Savelugu/Nanton Municipal of Northern region of Ghana.

\subsection{Methods of Data Collection}

Methods of data collection employed in this study were the use of questionnaire and interview guide. Questionnaires and interview guides are basically the same kind of instrument, that is, a set of questions to be answered by the subjects of the study [2]. However, there are some differences in how they are administered. In a questionnaire the subject responds to questions by writing or more commonly, by marking an answer sheet. Items to be selected on questionnaires include multiple-choice, true or false, matching, or interpretiveexercise questions. Interview guide is conducted orally and the answers to the questions are recorded by the researcher or anyone trained by the researcher [3].

\subsection{Population of the Study}

The population of the study refers to the entire group or category of individuals selected for the research [4]. For this study, the population comprised of:

All the women groups who are beneficiaries of the E4L programme in the Savelugu/Nanton municipal;

All the E4L programme beneficiary farmer groups of the Savelugu/Nanton municipal; and

All E4L staff in the Savelugu/Nanton municipal E4L programme office.

\subsection{Sampling Technique and Sample Size}

Sampling enables the researcher to study a relatively small number of units of the target population, and to obtain a data that is representative of the whole population. In most cases, however, the researchers opt for an incomplete coverage and study only a small proportion of the population - a sample. Sampling is thus, the process of choosing the research units of the target population, which are to be included in the study [5]. A sample is defined as a sub-set of or portion of the total population. It must always be viewed as an approximation of the whole rather than the whole itself [2]. There are different ways or techniques involved in the selection of a sample for any study. A sample technique therefore refers to the researcher's method of appropriately selecting the type, size and representativeness of the sample.

Out of several project interventions that are implemented in the Northern region, the purposive sampling technique was 
used to select the Empowerment for Life (E4L) programme for the study. Out of the five operational districts (Karaga, Mion, Saboba, Kumbungu and Savelugu/Nanton) of the Empowerment for Life (E4L) programme, the Savelugu/Nanton municipal was selected through simple random sampling. The simple random sampling technique was again used to select ten beneficiary groups, out of a total of seventeen beneficiary groups in the Savelugu/Nanton municipal, for the study. The beneficiary groups consisted of five women's groups and five farmer groups.

The purposive sampling technique was used to select 45 beneficiary farmers, 40 beneficiary women and 5 members of E4L staff. In all, 100 respondents were selected for the study. Purposive sampling is defined as a method of sampling where the investigator uses personal judgement to select a sample, which will provide the data needed, based on previous knowledge of the population [3]. The purposive sampling technique was used by the researcher to select the beneficiary groups and respondents because it was not all Empowerment for Life (E4L) programme beneficiary groups that were farmer and women groups. Some of the E4L beneficiary groups were engaged in other activities such as Peace Clubs (PCs), School Management Committees (SMCs) and Youth Centre Management Committees (YCMCs). So, the purposive sampling was the appropriate technique for selecting all the beneficiary farmer and women groups from the entire beneficiary groups.

\subsection{Development of Research Instruments}

The research instruments used during data collection were interview guide and questionnaire. The instruments comprised of a structure of open and closed-ended questions. Interview guide and questionnaires are a good way of collecting certain types of information (facts, views, opinions and perceptions) quickly and relatively cheaply as long as respondents are sufficiently disciplined to abandon questions that are superfluous to the main task [4]. The interview guide was employed for face-to-face interviewing of the beneficiary groups of the E4L programme. The questionnaires were self-administered. One set each of an interview guide and questionnaire were developed and used for the data collection in this study. An interview guide was used for the beneficiary farmer and women groups and questionnaire for the staff of E4L.

For the sake of reliability and validity, the questions were criticised, reviewed and revised many times by the researcher and his colleagues. The research instruments were pre-tested at Mbatinga in the Mion district of the Northern region where there was similar E4L programme intervention. This process exposed all inconsistencies, wrong expressions and inappropriate words in the prepared questionnaires, which resulted in making of the necessary corrections before they were taken to the field of study.

\subsection{Data Collection Procedure}

The researcher supported by two Empowerment for Life
(E4L) staff administered the questionnaires. The staff were trained over a two-day period to expose them to the import of the questionnaires with respect to the objectives of the research, and to teach them the skill of questionnaire administration. The interview guide for the farmer and women groups were interpreted into a Ghanaian local language (Dagbani) to enable respondents give appropriate answers. The questioning was done on a face-to-face interaction basis during the meeting with the members of the groups. The entire interview guide was read individually to ensure that the questions received the attention of respondents and was appropriately answered. The programme staff assisted in the recording of the responses from the respondents. This was necessary because the respondents were largely illiterates, and also to ensure that the responses came from the respondents themselves.

The questionnaire for the staff of Empowerment for Life (E4L) programme was self-administered. The selfadministered questionnaire method of data collection allows respondents to consult their files at their own convenience, and help them avoid bias and errors by the presence or attitudes of the interviewer [5]. This was the main reason why the questionnaire for the E4L staff was selfadministered.

\subsection{Method of Data Analysis}

The interview guide for the farmers and women groups were checked during and after each interview session to ensure that all the questions were answered. The selfadministered questionnaires from the E4L staff were also checked through to ensure that the data defined in the research instrument were actually collected and answers to all questions were properly recorded. Different coding manuals were developed for the different research instruments of the study. All responses were coded, and fed into a computer for statistical analysis using the Statistical Package for Social Sciences (SPSS). All the data from the farmers and women groups were analysed together. The analysis produced descriptive statistics of frequencies, counts and percentages. Cross tabulations of variables were done and the chi-square tests used to establish relationships. For visual impression and ease of understanding, summaries of findings were presented in tables.

\section{Results}

\subsection{Improving Food Security Among Beneficiary Farmers}

\subsubsection{Adoption of Improved Agronomic Practices}

The study revealed that the E4L beneficiary farmers were introduced to improved agronomic practices such as improved planting/sowing methods, fertilizer application, post-harvest loss management, use of improved crop varieties, good tillage practices and improved methods of chemicals application.

From the study, $46 \%$ of respondents have adopted three agronomic practices such as improved chemical application, 
planting methods and fertilizer application in their day-to-day farming activities (Table 1). In addition, $30 \%$ of the respondents adopted only two of the six improved methods of farming as introduced by the E4L programme. However, $4 \%$ of the respondents did not adopt any of the improved agronomic practices as introduced to them by the E4L programme.

Table 1. Adoption of improved agronomic practices by E4L beneficiary farmers.

\begin{tabular}{lll}
\hline $\begin{array}{l}\text { Adoption of improved } \\
\text { agronomic practices }\end{array}$ & $\begin{array}{l}\text { Number of } \\
\text { respondents }\end{array}$ & Percentage \\
\hline ICA + IPM + IFA & 23 & 46 \\
ICV & 10 & 20 \\
GTP + PHM & 15 & 30 \\
None & 2 & 4 \\
Total & 50 & 100 \\
\hline
\end{tabular}

Source: Field survey, 2020

Note: the total number of improved agronomic practices introduced to farmers by the E4L programme were six (6). These included; improved chemical application (ICA), improved planting methods (IPM), improved fertilizer application (IFA), improved crop varieties (ICV), good tillage practice (GTP) and postharvest loss management (PHM).

Changes Observed by Farmer Groups from use of Improved

\subsubsection{Agricultural Practices}

The study revealed that farmer groups experienced different changes resulting from the use of improved agricultural practices facilitated by the E4L programme. From the study, $56 \%$ of respondents experienced an increase in both quantity and quality of crops harvested, $22 \%$ observed a reduction in post-harvest losses and $18 \%$ experienced reduced time spent in weed control and fertilizer application (Table 2). In addition, $6 \%$ of the respondents indicated that they have experienced good prices for their farm produce.

Table 2. Changes observed by farmers after application of improved farming practices.

\begin{tabular}{lll}
\hline Change & Frequency & Percentage \\
\hline $\begin{array}{l}\text { Increased quantity and quality of farm } \\
\text { produce }\end{array}$ & 28 & 56 \\
$\begin{array}{l}\text { Reduced time spent in weed control } \\
\text { and fertilizer application }\end{array}$ & 9 & 18 \\
Reduced post-harvest losses & 10 & 20 \\
Good price for farm produce & 3 & 6 \\
Total & 50 & 100 \\
\hline
\end{tabular}

Source: Field survey, 2020

\subsubsection{Linking Beneficiary Farmers to Other Actors in the Value Chain}

The study established that the E4L programme linked farmers to other actors in the crop value chain. From Table 3, $38 \%$ of respondents strongly agreed they have been linked to other actors in the crop value chain, whilst $4 \%$ of respondents strongly disagreed.

Table 3. Linking beneficiary farmers to other actors in the crop production value chain.

\begin{tabular}{lll}
\hline Level of agreement & Number of respondents & Percentage \\
\hline Strongly agreed & 19 & 38 \\
Agreed & 26 & 52 \\
Disagreed & 3 & 6 \\
Strongly disagreed & 2 & 4 \\
Total & 50 & 100 \\
\hline
\end{tabular}

Source: Field survey, 2019

\subsection{Building Livelihood Assets of Farmers}

\subsubsection{Capacity Building}

The study established that E4L beneficiary farmer groups received capacity building trainings to improve on their livelihood assets. From the study, $46 \%$ of respondents strongly agreed that capacity building was beneficial in improving their livelihood assets, whilst $2 \%$ of the respondents strongly disagreed (Table 4).

Table 4. Capacity building among beneficiary farmers.

\begin{tabular}{lll}
\hline Level of agreement & Number of respondents & Percentage \\
\hline Strongly agreed & 23 & 46 \\
Agreed & 22 & 44 \\
Disagreed & 4 & 8 \\
Strongly disagreed & 1 & 2 \\
Total & 50 & 100 \\
\hline
\end{tabular}

Source: Field survey, 2020

\subsubsection{Information Sharing Among Beneficiary Farmers}

The study showed that there was information sharing among E4L beneficiary groups towards technology adoption and improvement on their food security. From the study, 50\% of the respondents strongly agreed that they share information among themselves and that information sharing influence their technology adoption. However, only $2 \%$ of the respondents strongly disagreed that information sharing among beneficiaries did not contribute to their technology adoption (Table 5).

Table 5. Information sharing.

\begin{tabular}{lll}
\hline Level of agreement & Number of respondents & Percentage \\
\hline Strongly agreed & 25 & 50 \\
Agreed & 20 & 40 \\
Disagreed & 4 & 8 \\
Strongly disagreed & 1 & 2 \\
Total & 50 & 100 \\
\hline
\end{tabular}

Source: Field survey, 2019

\subsubsection{Farmers Access to Productive Resources}

The study showed that the respondents' access to productive resources has increased. Access to land recorded $36 \%$ among the respondents, whiles, access to farm inputs and labour as productive resources both recorded 24\%, (Table 6). Access to capital scored the least of $16 \%$ among the respondents. 
Table 6. Access to productive resources by farmer groups.

\begin{tabular}{lll}
\hline Production resources & Number of respondents & Percentage \\
\hline Access to capital & 8 & 16 \\
Access to labour & 12 & 24 \\
Access to land & 18 & 36 \\
Access to farm inputs & 12 & 24 \\
Total & 50 & 100 \\
\hline
\end{tabular}

Source: field survey, 2019

\subsubsection{Mitigation Measures Adopted by Farmer Groups}

The study revealed farmers have alternatives in times of serious calamities to mitigate its impact. From the study, it was established that E4L farmer groups rely more on their savings $(56 \%)$ as a mitigation strategy in times of serious calamities (Table 7), whiles $36 \%$ resort to selling of property as their mitigation strategy. However, $6 \%$ of them go in for loans with another $2 \%$ relying on family members as a mitigation measure in an event of serious calamities.

Table 7. Mitigation measures adopted by farmer groups in the event of a serious calamity.

\begin{tabular}{lll}
\hline Mitigation measures & Number of respondents & Percentage \\
\hline Savings & 28 & 56 \\
Selling of property & 18 & 36 \\
Loans/borrowing & 3 & 6 \\
Rely on family & 1 & 2 \\
Total & 50 & 100 \\
\hline
\end{tabular}

Source: Field survey, 2020

\section{Discussion}

\subsection{Enhancing Food Security Among Beneficiary Farmers}

The study revealed that the Empowerment for Life (E4L) programme beneficiary farmers were introduced to improved agronomic practices such as improved planting/sowing methods, fertilizer application, post-harvest management, use of improved crop varieties, good tillage practices and improved methods of chemicals application; with the view to improving food security. The significant variation in the adoption of the improved agronomic practices as observed by the farmers could be due to farmers' limited economic capacities (land holdings and affordability of technology). This observation is in consonance with the assertion that farmers with large farm size are likely to adopt a new technology as they can afford to devote part of their land to try new technology, unlike those with less farm size [6]. Again, a study conducted on determinants of fertilizer and manure use in maize production in Kiambu, Kenya reported high cost of labour and other inputs as the main constraints to fertilizer adoption [7].

Failure of farmers to adopt any of the improved agricultural technologies, introduced to them by the E4L programme, could be due to their negative perception about those technologies.

It is also possible that the non-involvement of the farmers in the evaluation and introduction processes of the new technologies was the reason for the rejection of the new technologies.

Farmers' perception about the performance of the technologies significantly influences their decision to adopt them. This is in consonance with the reports that it was important to involve farmers in the evaluation of new technologies before introducing it to them, so they can assess its suitability to their circumstances [8].

The study revealed that farmer groups experienced various changes in their agricultural productivity as a result of the use of improved agricultural practices facilitated the E4L programme. Whilst some farmers recorded increased quantity and quality of farm produce, and reduced post-harvest losses, others recorded good prices for their produce. This resulted in an aggregate effect of improved food security. The modernization of agriculture by improving productivity, mechanization, irrigation and water management, reducing post-harvest losses and improving storage and distribution systems through capacity building of relevant stakeholders was the surest way of reducing food insecurity among farmers in northern Ghana [9].

\subsection{Building Livelihood Assets of Farmers}

From the study, majority of the beneficiary farmers agreed that capacity building was beneficial in improving their livelihood assets, since the knowledge transferred to farmers would have contributed to improving on their human capital. This assertion is in line with the observation made by [10] and [11] that human capital plays a crucial role in accelerating agricultural productivity by learning, applying and disseminating technical knowledge. Capacity building also influences a farmer's capability to adjust new technology in particular circumstances as a changing demand. It was also observed that farmer's education and extension services have enhanced the production of Korean, Thai and Malaysian farms [12].

The beneficiary farmers revealed that sharing of information has contributed to improved technology adoption among themselves. Farmers within a social group learn from each other the benefits and usage of a new technology [13]. In addition, it was suggested that social network effects are important for individual decisions, and that, in the particular context of agricultural innovations, farmers share information and learn from each other [6].

The study revealed that farmers have alternatives in times of serious calamities to mitigate its impact. From the study, it was established that majority of E4L farmer groups rely more on their savings as their mitigation strategy in times of serious calamities.

It has been asserted that women participating in BRACsponsored activities have more assets and are more often gainfully employed than non-participants [14]. It has also been confirmed that the BRAC members have better coping capacities in lean seasons and that these increased with length of membership and amount of credit received from BRAC [15].

In spite of the issues of culture, religion and norms that impede access to productive resources, especially among women, the 
percentage of farmers who gained access to productive resources in the E4L operational areas were high. This could have been due to the E4L programme intervention that sought to campaign for equity in access to productive resources.

Cultural and institutional factors often limit women's access to land, labour and capital [16]. They added that, access to land is often restricted to usufruct rights (that is, women cannot provide collateral for credit because they may not have legal ownership of tangible assets). In addition, it has been noted that discrimination, a situation where unequal opportunities are given to some people to participate in the production process based on gender, age and ethnic considerations has impeded livelihood activities a great deal particularly among women [17].

\section{Conclusion}

The study revealed that majority of the beneficiary farmers have had improved food security through the adoption of improved agronomic practices and improved linkage between farmers and other actors in agricultural value chain.

The study further established that the livelihoods of beneficiary farmers have been improved through improved capacity building, information sharing and improved access to productive resources such as land, labour and farm inputs.

The study also revealed that in times of difficulties, majority of the farmers relied on their savings and/or sale of property as the mitigation measure or coping strategy.

\section{Recommendation}

It is recommended that capacity building of farmers on agronomic practices and improved modern methods of farming should be intensified to further sharping the skills of farmers for increased productivity and hence, improved food security and livelihoods.

It is further recommended that the E4L programme be extended to cover all districts in the Northern region of Ghana.

\section{Conflict of Interests}

The Authors declared that they have no competing interest

\section{Acknowledgements}

We do acknowledge the critical comments and scientific inputs made by all researchers at the Millar Institute for Transdisciplinary and Development Studies, Bolgatanga, Ghana.

\section{References}

[1] PHC, 2010. The 2010 Population and Housing Census (PHC) reports: Analysis of district data and implications for planning. Published by the Ghana Statistical Service, Accra, Ghana; 2010.
[2] Bailey, K. D., 1987. Methods of Social Research, the Free Press, New York.

[3] Fraenkel, J. R. and Wallen, N. E., 2000. How to Design and Evaluate Research in Education, $4^{\text {th }}$ Ed. McGraw Hill Inc., USA.

[4] Bell, J., 1993. Doing your Research Project: A guide for first time researchers in education and social science, Open University Press, UK.

[5] Sarantakos, S., 1993. Social Research, Macmillan Education Pty Ltd., Australia.

[6] Uaiene, R., Arndt, C., Masters, W., 2009. Determinants of Agricultural Technology Adoption in Mozambique. Discussion papers No. 67E.

[7] Makokha, S., Kimani, S., Mwangi, W., Verkuijl, H., Musembi, F., 2001. Determinants of Fertilizer and Manure Use for Maize Production in Kiambu District, Kenya. CIMMYT (International Maize and Wheat Improvement Center) Mexico.

[8] Karugia, S., Baltenweck, I., Waithaka, M., Miano, M., Nyikal, R., Romney, D., 2004. Perception of Technology and its Impact on Technology Uptake: The Case of Fodder Legume in Central Kenya Highlands. The Role of Social Scientists Proceedings of the Inaugural Symposium, 6 to 8 December 2004, Grand Regency Hotel, Nairobi, Kenya.

[9] Bawa, A., 2019. Agriculture and Food Security in Northern Ghana. Asian Journal of Agricultural Extension, Economics $\begin{array}{lllll}\text { and Sociology } & 31 & (2): & 1-7 & \text { DOI: }\end{array}$ 10.9734/ajaees/2019/v3li230127.

[10] Romer, P., 1986. "Increasing Returns and Long Run Growth". Journal of Political Economics 94: 1002-1037.

[11] Lucas, R., 1988. "On The Mechanics of Economic Development". Journal of Monetary Economics 22: 3-42.

[12] Jamison D., and Lau, L., 1982. "Farmer Education and Farm Efficiency". Washington, DC, World Bank.

[13] Mignouna, B., Manyong, M., Rusike, J., Mutabazi, S. and Senkondo, M., 2011. Determinants of Adopting ImazapyrResistant Maize Technology and its Impact on Household Income in Western Kenya: AgBioforum, 14 (3), 158-163. Hall, B. and Khan, B. (2002) Adoption of new technology. New Economy Handbook.

[14] Chowdhury, A. M. R., Mahmud, M. and Abed, F. H., 1991. Impact of Credit for the Rural Poor: the case of BRAC Small Enterprise Development, Volume 2, No. 3. IT Publications, London.

[15] Mustafa, S. and Ara, 1996. Beacon of Hope: An Impact Assessment of BRAC's Rural Development Programme, Dhaka, BRAC Evaluation Division.

[16] Quisumbing A. R., Payongayong, E., Aidoo, J. B., Otsuka, K., 2001. Women's land rights in the transition to individualized ownership: implications for tree resource management in Western Ghana. Econ Dev Cult Change, 50 (1): 157-82.

[17] Ogwumike F. O., 2001. Current state of knowledge on poverty in Nigeria. In: Afonja, S., Adelekan, D., Soetan, F., Alimi, T. and Ayanwale, B. (Eds). Research and policy directions on poverty in Nigeria. Nigeria: Centre for Gender and Social Policy Studies; 2001. p. 24-34. 